\title{
Higher Education Branding in Africa: A Social Media Perspective
}

\author{
Kehdinga George Fomunyam \\ Teaching and Learning Development Centre, Mangosuthu University of Technology, Durban, South Africa
}

Received May 31, 2020; Revised September 4, 2020; Accepted October 28, 2020

\section{Cite This Paper in the following Citation Styles}

(a): [1] Kehdinga George Fomunyam, "Higher Education Branding in Africa: A Social Media Perspective," Universal Journal of Educational Research, Vol. 8, No. 12, pp. 6941 - 6952, 2020. DOI: 10.13189/ujer.2020.081261.

(b):Kehdinga George Fomunyam (2020). Higher Education Branding in Africa: A Social Media Perspective. Universal Journal of Educational Research, 8(12), 6941 - 6952. DOI: 10.13189/ujer.2020.081261.

Copyright $\mathrm{C} 2020$ by authors, all rights reserved. Authors agree that this article remains permanently open access under the terms of the Creative Commons Attribution License 4.0 International License

\begin{abstract}
The global higher education landscape has continued to experience changes and transformation, and there have been various contextual evidences that globalization has been a major contributor to this change. As a result of globalization, higher education institutions become more marketable and the need for brand building has increased. Over the years, there have been various attempts by higher education institutions to boost and improve their public image, and this has necessitated corporate visual identity and some changes to their names. This research is an inquiry into higher education branding in Africa using the social media perspective. Evidences were culled from the websites of universities in East Africa, West Africa, North Africa, South Africa, and Central Africa. Two institutions were selected from the regions and how they have branded themselves and established themselves on social media was considered. With various institutions offering service to members of the public, there are various avenues for dishing out information and engaging their prospective clients. The notable platforms these institutions use include Facebook, twitter, Instagram, LinkedIn and YouTube. This study recommends that the mandate by which each institution was established should be incorporated into their brand identities and propagated via social media. There should be an audit of all social media pages to understand engagement levels across all platforms, and to proffer other ways of branding to the institution.
\end{abstract}

Keywords Higher Education, Branding, Africa, Social Media, University

\section{Introduction}

The global higher education landscape has continued to experience changes and transformation and there have been various contextual evidences for this change, globalization has been a major contributor to this change (Altbach, P\& Knight, J, 2007: Altbach, P.G, Reisberg, L \&Rumbley, L.E. 2009). There has been more demand for higher education as universities compete globally to attract students (UNESCO, 2020). According to British Council (2020), Higher education globally has internationalization of teaching and research, raising quality standards and global relevance, attracting the best pool of students and staffs, ensure increase in revenue generation and pushing the frontiers of knowledge through research and encouraging internal diversity. This has led to massive proliferation of various private or public universities. In Africa, universities were seen in the light of development (Cloeteet al, 2011) and the state public sector institutions were key to the development of Africa (Varghese, 2013).

As a result of globalization, higher education institutions have been more marketable and the need for brand building tends to increase. Over the years, there have been various attempts by University to boost and improve their public image and this has necessitated corporate visual identity and some changes to their names. Branding is now a major part of the higher education domain and this enables them to compete with others in the global market. The branding of higher education is also necessitated by the worldwide search for students and the constant search for research funding and fame (Deem et al 2008). With globalization, there has been development of various technologies that has helped branding activities in Higher education but there 
are differences across various spaces because the globalization process flow differently across various regions.

Despite the prevalence of branding in higher education in Africa over the years, there have been few studies on branding in higher education in Africa using the social media perspective. This study aims to explore the branding strategies of African higher education institutions using the social media perspective. Focus will be on the University website and social media pages to understand how the institution projects itself as a brand to the world. This study will shed light on the branding practices of universities in Africa, and provide recommendations to improve visibility and corporate profile of the institutions.

\section{Methodology}

This research is an inquiry into higher education branding in Africa using the social media perspective. This study adopted a qualitative case study approach to gather evidences from different African regions, in a bid to understand and compare patterns that support the purpose of this study. As stated by Cohen et al., (2011), a case study is a comprehensive examination of a particular case in its context, to aid data generation. While a qualitative research approach gathers detailed empirical data from several sources such as documents and introspections which describe the phenomena in details (Denzin\& Lincoln, 2012). This study focuses on gaining understanding on branding of African higher education institutions, using perspectives from social media.

Evidences were culled from the websites of universities in 5 different African regions, East Africa, West Africa, North Africa, South Africa, and Central Africa. Two institutions were selected from each region, and these institutions were investigated to determine their mode of branding via social media. For East Africa, the University of Nairobi, Kenya, and Makerere University, Kampala were selected. The University of Capetown, and the University of Witwatersrand were both selected from the South African region, while the University of Ghana, and the University of Lagos were selected from the West African region. For North Africa, Cairo University, and the American University in Cairo were both selected to represent the region. Finally, the University of Dschang, and the University of N'djamena were both selected from the Central African region. All institutions selected were purposely selected and sampled individually. purposive sampling is used to generate data from people/institutions who have specialised knowledge in a field(Chithra and D'Almeida, 2014).

This study utilized different social media instruments to generate data, and they include Facebook, Twitter, Instagram, LinkedIn, and Youtube. Social media has been an avenue to engage with a broad range of stakeholders in the entire demography with far reaching influence on the youth. Focus was on the University website and their social media pages such as Facebook, twitter and Instagram. The means of engagement were considered, frequency of engagement, target audience and content creation strategy were also investigated.

\section{Branding of Higher Education in Africa}

Looking at branding, it was reported that the word comes from the Old Norse Brandr which is to burn. Branding as a concept has been used to showcase ownership of property and this was confirmed when certain scars and markings were used to establish ownership of a certain product in the olden days (Van den Heever, 1993: Johnson, 2005).

There are many definitions of branding and various authors have defined the word. Stewart (2004) opined that branding has been a major topical issue on business agenda today and the reason was attributed to the fact that a business entity needs to send messages to the crowded marketplace in a unique manner that differentiates the products and services. Branding also offers the opportunity for organizations to stand out amongst others. There are many higher education institutions which only have the same of developing the knowledge bank of students. But to do this, they come to the fore with various differentiating factors that make them peculiar to others which also ensures that their services are appealing to their target audience. The world is replete with various persons, institutions, bodies, government countries doing the same thing over the years. What makes the difference is the ability to stand out amongst the crowd.

Brand according to Stewart (2004) is more than the nomenclature. It was further opined that brands are beliefs, values, services and experiences that is inherent in a name. This implies that branding is like a promise to be delivered based on certain indices mentioned above such as beliefs, values, services and experiences. Going forward from this, an interaction with your brand will leave people with some impression about your beliefs, values, services and experiences and this forms their perception about you as a brand. Mariotti (2000) maintained that a brand or a brand name is a short, simplified, description of a bouquet of values which prospective clients and consumers can depend on over a certain period of time. This implies that much more than the interaction between an establishment and its client, there is the need for value exchange to describe aptly branding.

Mariotti (2000) went a notch higher when he opined that a brand is just a word. It is a composite of the business strategy, DNA, image, marketing, concept and all that the business entails. A more vivid description of brand was given by Roll (2004) and he defined brand as a name, term, symbol, association, trademark, design etc. which is aimed 
at identifying a product or service to prospective customers and to standout from other competitors. The import of this definition is that a brand is helpful in creating a union between the customers and the product or service. As the product or service becomes attractive and appealing to the customer through various branding strategies, he gets attached and drawn to the product or service and there is a relationship.

Building brands (2004) defined brand as the most precious real-estate in the world, which forms a corner of the consumer's mind. This typifies the importance of branding to any business setup as a valuable currency that can ensure that the business survives among others. Through branding, an image is emblematized on the mind of the consumers be it positive or negative based on your experience with your organization as a brand.

In the higher education landscape, Moore (2004) maintained that brands of higher education are only limited to the eye of the beholder. It is a mix of the impression of the content, character, quality that an institution offers to the prospective students. Branding according to Moore (2004): Sevier (2004) is a promise. It is a promise that must be delivered to students, alumni, prospective students, the society at large, and the higher education institution itself.

The higher education landscape in Africa is constantly evolving and there are establishment of more universities to cater for the large number of students seeking for admission. As a result of the competition in the higher education landscape, each institution has relied on branding to create a niche for themselves (Makgosa\&Molefhi, 2012: Mogaji, 2018). It has also been observed that having a strong brand has always ensured competitive advantage in the higher education sector because prospective students and other clients will want to be associated with an established brand that has been known. Branding and corporate identity is important as core factors in corporate and marketing strategy (Opoku, Abratt\& Pitt, 2006) and higher education institutes are becoming more interested as corporation with brand strategies (Velostsou, Lewis \& Paton, 2004).

\section{The Importance of Branding in Higher Education System}

Branding is important in higher education system as it helps to articulate the essence of the institution in an increasingly competitive market and it helps to showcase and communicate signs of quality (Balajiet al, 2016). It is important to clearly communicate with the public about what the institution is all about, prove to the world the worth of the institution, and signs that separates them from other institution in terms of quality. With various institutions in the society, what they offer in terms of value is different and also the core essence of each institution is different. What distinguishes each institution from each other in terms of the aforementioned metric is branding. Each country is moving towards a commercialized higher education domain and branding is necessary to distinguish one institution from the other. Branding in higher education is also a crucial avenue for future brand theory and practice (Melewar and Nguyen, 2014). A research by Chapleo and Clark (2016) revealed how a branding committee in university was used to facilitate the university's branding process.

Branding is also a tool for higher education institutions to increase the number and quality of students (Belanger et al, 2002: Suomi, 2014). In instances where there is reduction in enrollment rate, the higher education institution often engages in branding to increase the popularity of the university, attract prospective students and showcase to the world what the institution will offer them.

Furthermore, branding encourages student loyalty (Helgesen and Nesset, 2007). Having a well spelt out vision and mission communicates to the students the ideals of the institution and this is reinforced by branding. With branding, the ethos of the school is emblematized on the heart of the students and this guides there conduct within and without the academic institution. This therefore encourages student loyalty in the higher education system.

In order to improve synergy between members of the institution and those that have left the institution, branding is important. This is revealed in the works of Ressler and Abratt (2009) where they maintained that branding improves alumni links. With well-coordinated branding strategies, it has the potential to bring all stakeholders within and outside the institution together. This has been influenced greatly by globalization that saw to the emergence of various technologies that brings people together across the globe. A well branded institution attracts quality talents as staffs (Whisman, 2009) and gain support from the corporate sector (Baker et al, 2005).

Another notable importance of branding is that it helps to distinguish universities from other actors in higher education (Scarborough, 2007). Through Branding, the uniqueness of each university is communicated to the public.

\section{Branding of Higher Education Using a Social Media Perspective}

The social media has been a vital tool for branding and in recent times, the advancement made in technology has made that possible. People now have access to computers, phones, internet and other communication devices. To lay a foundation for higher education in Africa, 10 universities were selected using the keyword "top universities in each region" to search and the first two institutions that popped up from the search engine were selected. 
Table 1. List of universities selected from each region in Africa

\begin{tabular}{|c|c|c|}
\hline $\mathrm{s} / \mathrm{n}$ & Region & Universities \\
\hline 1 & East Africa & $\begin{array}{c}\text { University of Nairobi Kenya } \\
\text { Makerere University Kampala }\end{array}$ \\
\hline 2 & South Africa & $\begin{array}{c}\text { University of Cape town } \\
\text { University of Witwatersrand }\end{array}$ \\
\hline 3 & West Africa & $\begin{array}{c}\text { University of Ghana } \\
\text { University of Lagos }\end{array}$ \\
\hline 4 & North Africa & $\begin{array}{c}\text { Cairo University } \\
\text { American University in Cairo }\end{array}$ \\
\hline 5 & Central Africa & $\begin{array}{c}\text { University of N'djamena } \\
\text { University of Dschang }\end{array}$ \\
\hline
\end{tabular}

To understand higher education in Africa using the social media perspective, this study will consider the University website and links to other social media pages from the website.

The University website is a tool that ensures easy communication between students, faculty, alumni and visitors. According to Broadband et al (2010), the website is applicable to primary audience, students etc. to communicate on academic and non-academic matters. The University is a body offering value to a whole collection of people and there is a need to release information to them. There is a need to provide information and basic statistical data within the University environment, admission and scholarship information, ceremonies and social events, University history, library information etc. having such website provides the students the opportunity to make full use of the academic services offered by the University (Kang and Norton, 2006).

The University of Nairobi is a corporate body established by an Act of Parliament Cap 210 of the Laws of Kenya and the pioneer institution of University education in Kenya and the region. The only institution of higher learning in Kenya is a major contributor to national regional and Africa's high level manpower training needs by developing and evolving strong, diversified academic programmes and specialization in sciences, applied sciences, technology, humanities, social sciences and the arts. The range of programmes offered in the institution is about two hundred(uonbi.ac.ke/about-us, 2020).

The University website must be creative to allow prompt interaction with the user. A glimpse at University of
Nairobi, Kenya's website(https://www.uonbi.ac.ke/) shows the landing page with links to other pages and social media platforms such as Facebook, twitter, Instagram and YouTube. There are recent contents (pictures and texts) on the websites which shows that the site is often updated. There is a link for tweets to appear on the website which is all part of branding. To dive deeper into how the institution brands on social media, links on the website to their social media pages were checked. From the institutions Facebook page(https://web.facebook.com/uonbi.ac.ke/), there are contents on latest developments, events, public lecture, orientation, inauguration etc. on the website with accompanying texts and videos.

There are recent uploads on the social media page which shows that it is a major avenue whereby the institution dishes out useful information as part of its branding strategy. Also, the Facebook page of University of Kenya shows huge followership (42091). There are various links for about, posts, photos, videos, events etc. on the Facebook page of the institution. On twitter, University of Nairobi has maintained itself as a brand with great engagement on the platform. There are evidences of engagement as a brand on twitter as a result of the likes and retweets of contents coming from the institution. The twitter handle (https://twitter.com/uonbi) for University of Nairobi Kenya has huge followership (90300 followers). On the Instagram page, there are evidences of engagement on the page though not prominent unlike Facebook and twitter. This might be attributed to the fact that Instagram is more of images and people tend to rely on other channels for information on education. As a brand on Instagram, the institution has small followership (2307) and Instagram as a social media platform might not be the best for the institution. The institution as a brand also engages on YouTube(https://www.youtube.com/user/UniverstiyofNai robi/videos) and they dish out videos through the platform. There are evidences of engagement on the platform as visual contents were posted often. The institution has 822 subscribers on YouTube. There's uniformity in terms of brand identity on all the social media platforms for University as the same profile picture was used. The institution has no LinkedIn page. 


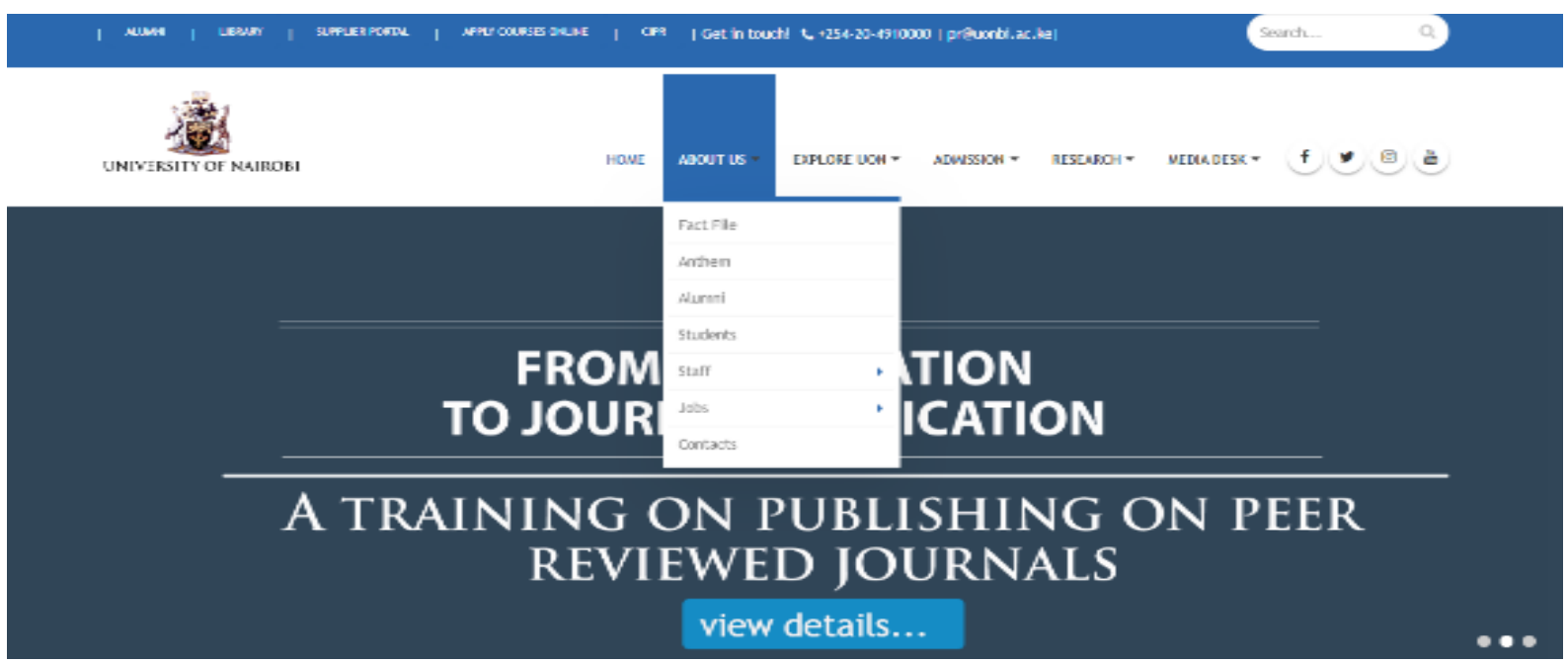

Plate 1. Institutional website for University of Nairobi Kenya

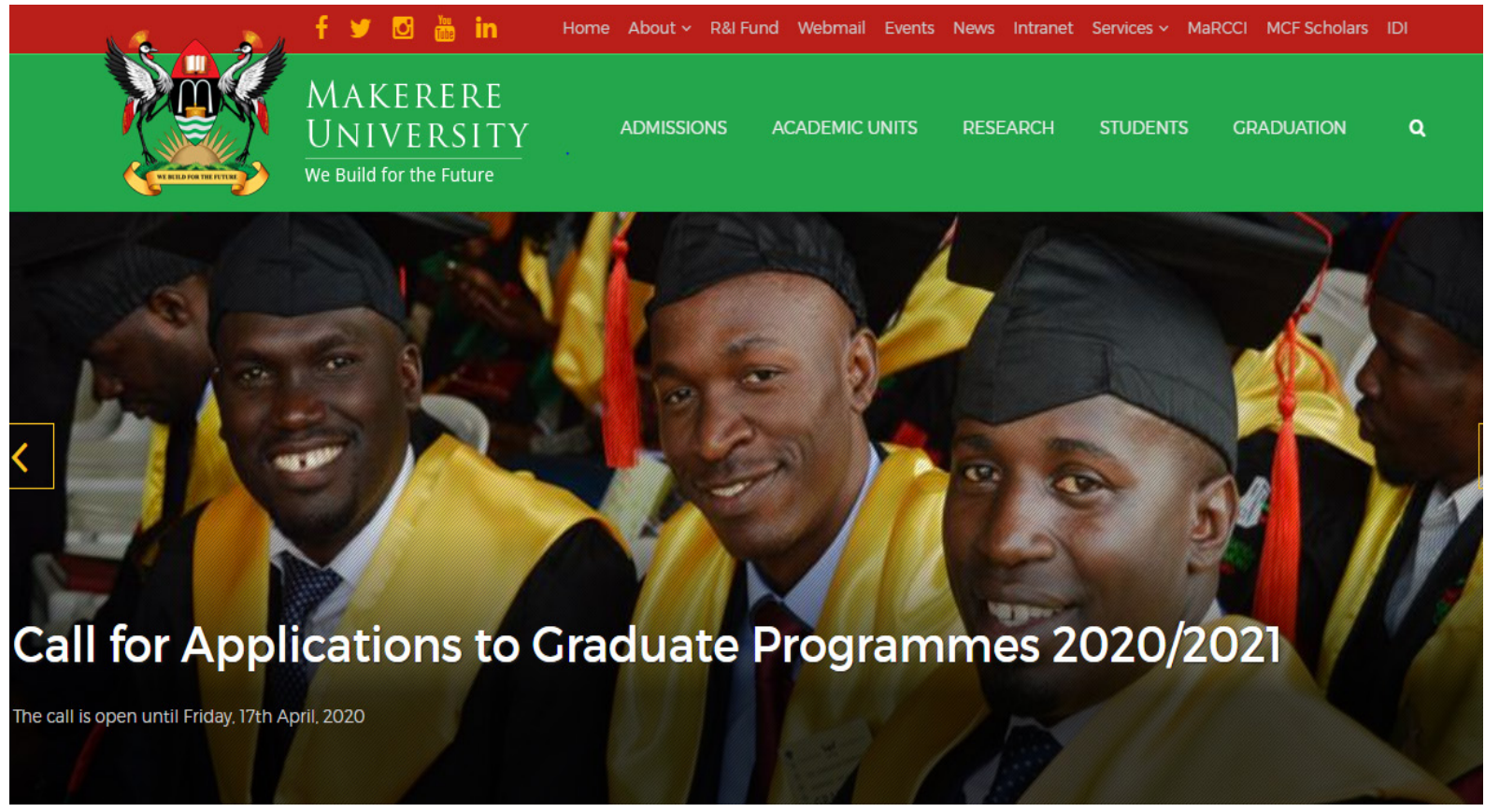

Plate 2. Official website for Makerere University

Makerere University Kampala is Uganda's largest and oldest institution of higher learning and it was first established as a technical school in 1922 and it became an independent national University in 1970. Makerere University Kampala has a functional website that shows engagement (https://www.mak.ac.ug/). There are evidences of engagement from the pictures, texts, and events on the website. There are also directories to other links to meet the needs of their potential clients. There is also a video on the landing page of the institution. The logo is well placed and its conspicuous as a tool for brand identity on the platform. On the Facebook page, there are evidences of engagement on the page and the institution has massive followership on Facebook (270144). There are pages for about, posts, events, photos, videos on the Facebook page (https://web.facebook.com/Makerere?_rdc
$=1 \&$ rdr). On twitter, the institution is verified with the blue tick and it shows certain level of credibility as a brand. The twitter page is active with recent contents pertaining to the institution evidenced by likes and retweets. The institution also has large followership on twitter (112800).

On Instagram, the brand (https://www.instagram.com/ MakerereU/) is also verified with the blue thick giving it more credence. There is evidence of content creation strategy on the page with good engagement from the followers. The brand has less followership on Instagram (8688) compared to twitter and Facebook. On YouTube, the institution has 829 subscribers and the page is less active as it was last updated four months ago(https://www.youtube.com/user/Makereretube). The institution does not properly utilize YouTube as a social media platform for engagement as a brand. The 
institution has no LinkedIn page.

University of Cape Town is an inclusive and engaged research-intensive African University that inspires creativity through outstanding achievements in learning, discovery and citizenship, enhancing the lives of its students and staff, advancing a more equitable and sustainable social order and influencing the global higher education landscape(uct.ac.za). University of Cape Town has a website (https://www.uct.ac.za/) and the landing page is a bit busy. There are evidences of engagement on the website as various contents are posted regularly. There are links to other social media pages on the website. On Facebook(https://web.facebook.com/uct.ac.za/? rdc $=1 \&$ rdr), the brand has 202361 followers. There are proofs of content creation strategies on the Facebook page as a brand with engagements from followers. The logo as a brand identity is a bit insignificant. The institution is also active as a brand on LinkedIn and various updates are posted there (https://www.linkedin.com/school/University-of-cap e-town?pathWildcard=7936) with 215882 followers. On twitter, the institution is verified with the blue thick and it has wide followership (203900k). There is uniformity in terms of contents across all social media platform. On YouTube (https://www.youtube.com/user/UCTSouthAfric a/playlists) the institution brands itself with various videos that have to do with the institution. Overall, the brand on all the social media platforms considered has poor visibility for the brand logo.

University of Witwatersrand is a multi-campus South African Public University situated in the northern area of central Johannesburg. University of Witwatersrand website was inaccessible at the time of this study. The institution has an optimized LinkedIn page with basic information relevant to the institution. There is also engagement on the platform with recent post from it. On LinkedIn (https://www.linkedin.com/school/University-of-the-witw atersrand/), the institution has 195628 followers. On Facebook

(https://web.facebook.com/witsUniversity/?_rdc=1\&_rdr), the brand has a video as a cover and the institution has 195966 followers and there are evidences of engagement with people from the recent posts made on the page. On twitter, the institution as a brand has a verified twitter page (https://twitter.com/witsUniversity) with large followership (104800) and engagement as a branding strategy. There are evidences of interaction with the audience from the tweets captioned with pictures and videos. Events and other issues pertinent to the institution are tweeted frequently on the twitter page. On YouTube (https://www.youtube.com/user/WitsWebmaster/videos), the institution has 7007 followers with visual content being updated once in a while.

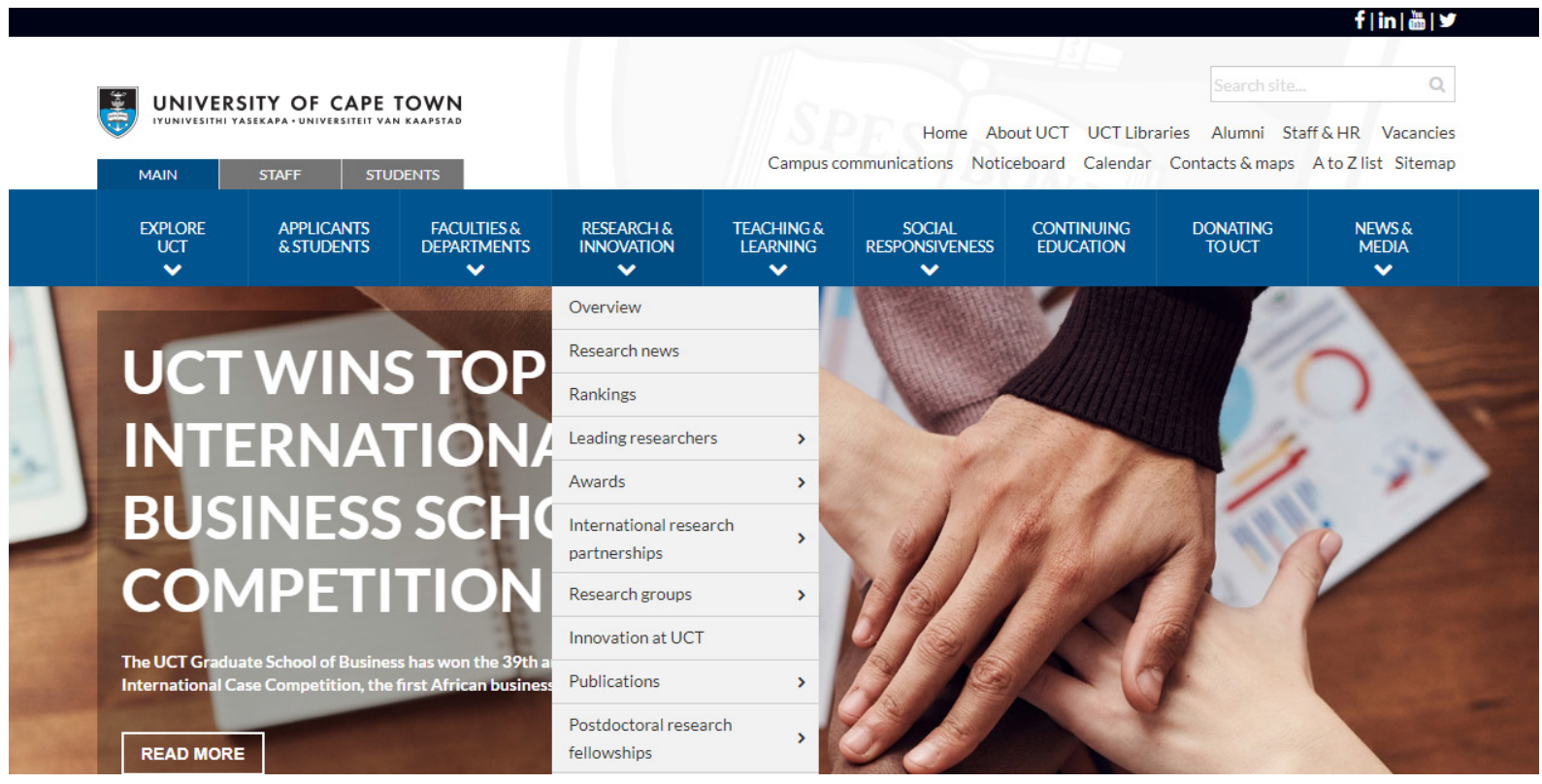

Plate 3. University of Cape Town Website 


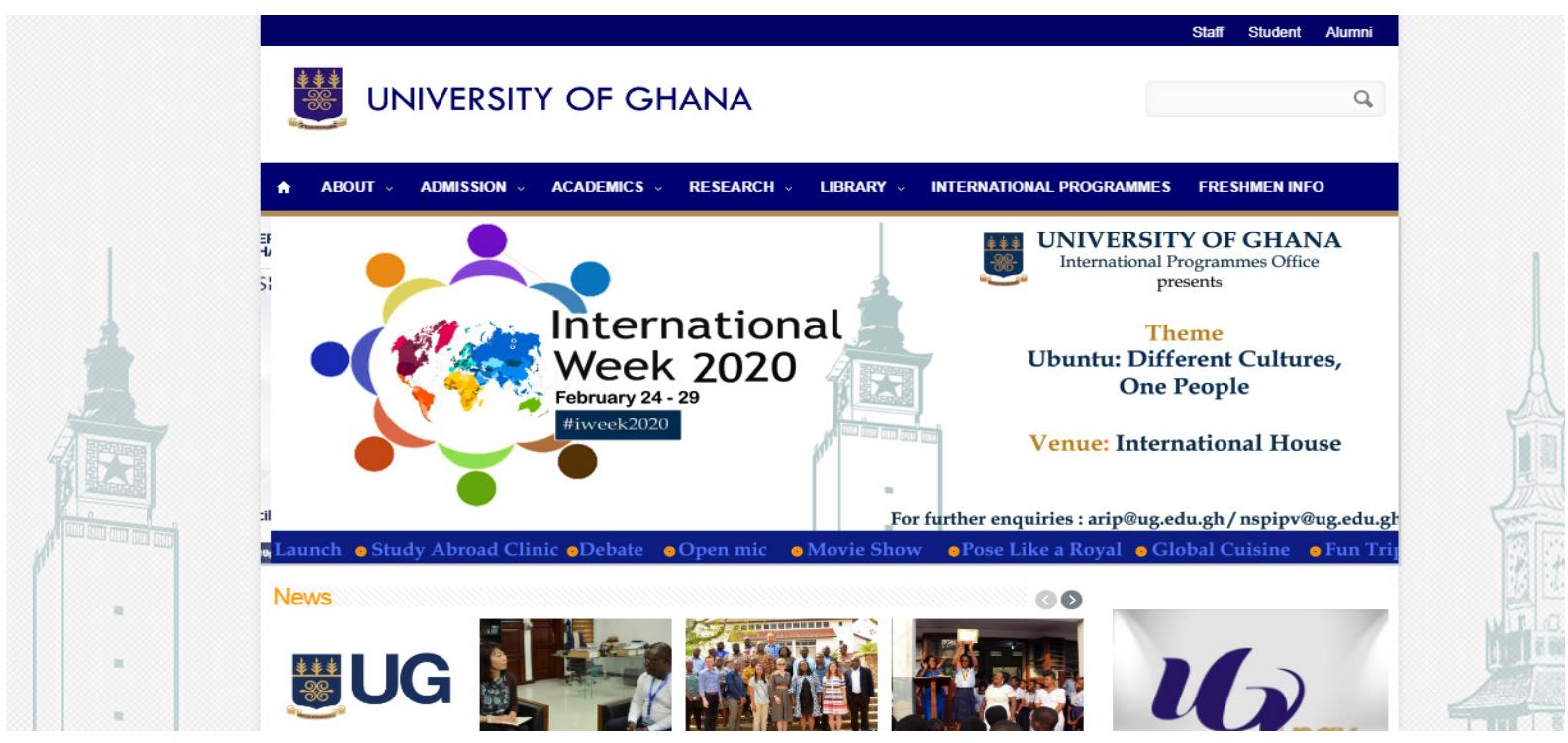

Plate 4.The official website of University of Ghana

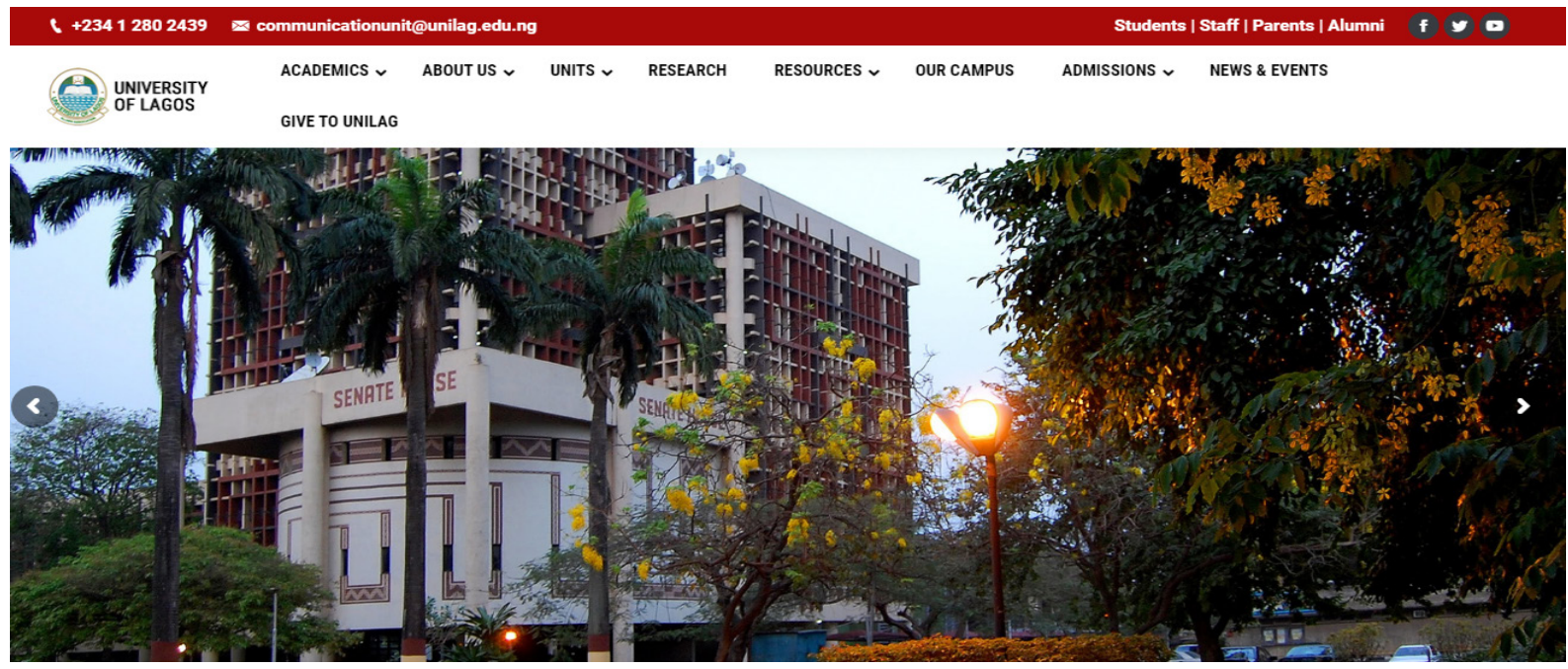

Plate 5. University of Lagos website

University of Ghana is the premier University and the largest University in Ghana which was founded as the University college of the Gold Coast by ordinance on august 11, 1948 for the purpose of providing and promoting University education, learning and research (ug.edu.gh/about/overview). University of Ghana has an active website (https://www.ug.edu.gh/) through which information is being passed to the public. The website has links to other social media pages of the institution which they use for projecting the brand to the world. On twitter, the institution is unverified with low followership (14300). There are recent tweets on the timeline though not active compared with other institutions. On YouTube, the institution has 4009 subscribers with visual contents posted once in a while. The institution has no active Facebook page.

University of Lagos was founded in 1962 and it presently has three campuses in Yaba and Surulere, whereas two of its campuses are located in
Yaba(unilag.edu.ng/?page_id=7). University of Lagos has an active website (https://unilag.edu.ng/) which is updated constantly. The landing page is good with bold images that shows the University environment but the logo as a brand identity is inconspicuous. The website has links to other social media pages such as Facebook, twitter and YouTube.

On Facebook, the institution engages with people via their contents. The Facebook page (https://web.facebook.com/OfficialUniversityOfLagos/?_r $\mathrm{dc}=1 \&$ rdr) has an automatic bot which pops up immediately a user enters the site. There are evidences of engagement on the page from recent contents posted. The institution has low followership (16469) compared with other institutions. The brand is unverified on twitter (https://twitter.com/unilagnigeria?lang=en) with low followership (16000). The institution uses twitter as a platform for pushing itself out as a brand and this is seen in the tweet posted daily. On 
youtube(https://www.youtube.com/channel/UCmKa7PfQJ TutSTdv1ApYjPw), the institution has 574 subscribers with visual contents posted once in a while.

Emergence of Cairo University and its development helped the Egyptian patriotic movement in the early $21^{\text {st }}$ century. Cairo University is Egypt's premier public University. Cairo University's website has a good landing page with bright and well lit-up image of the institution. This is important as a branding strategy to attract people. It also has link to other pages on the landing page. The landing page is a bit too wordy and most of the content there has little images to support them. On Facebook, the institution has a bot that chats with you when you are logged to the website and it has huge followership (560633). The Facebook page is verified and authentic (https://web.facebook.com/cu.edu.eg? rdc $=1 \&$ rdr) is active with recent contents from the institution and engagement. The twitter page (https://twitter.com/CairoUniv) for the institution is active with poor engagement and low followership (6830) and the tweets are in Arabic. It is also unverified. This might be a major constraint from reaching a wider audience. On YouTube(https://www.youtube.com/user/TheCairoUn iversity/videos) the University has 1023 subscribers visual content updated once in a while.

American University Cairo was founded in 1919 and it's a leading English language American-accredited institution of higher education and center of intellectual, social and cultural life of the Arab world (aucegypt.edu/about/about-auc). American University Cairo has an active website (https://www.aucegypt.edu/) with contents posted frequently for engagement. YouTube feeds were also incorporated into the website. The website has a cover video to welcome people and to know more about the institution. The institution has 154547 followers on LinkedIn (https://www.linkedin.com/school/american-University-in -cairo/) with recent posts and relevant information about the institution on the page. On Youtube (https://www.youtube.com/user/AUC), the institution has 13600 subscribers. The brand is verified on twitter though with 28100 followers and active tweets and engagement.

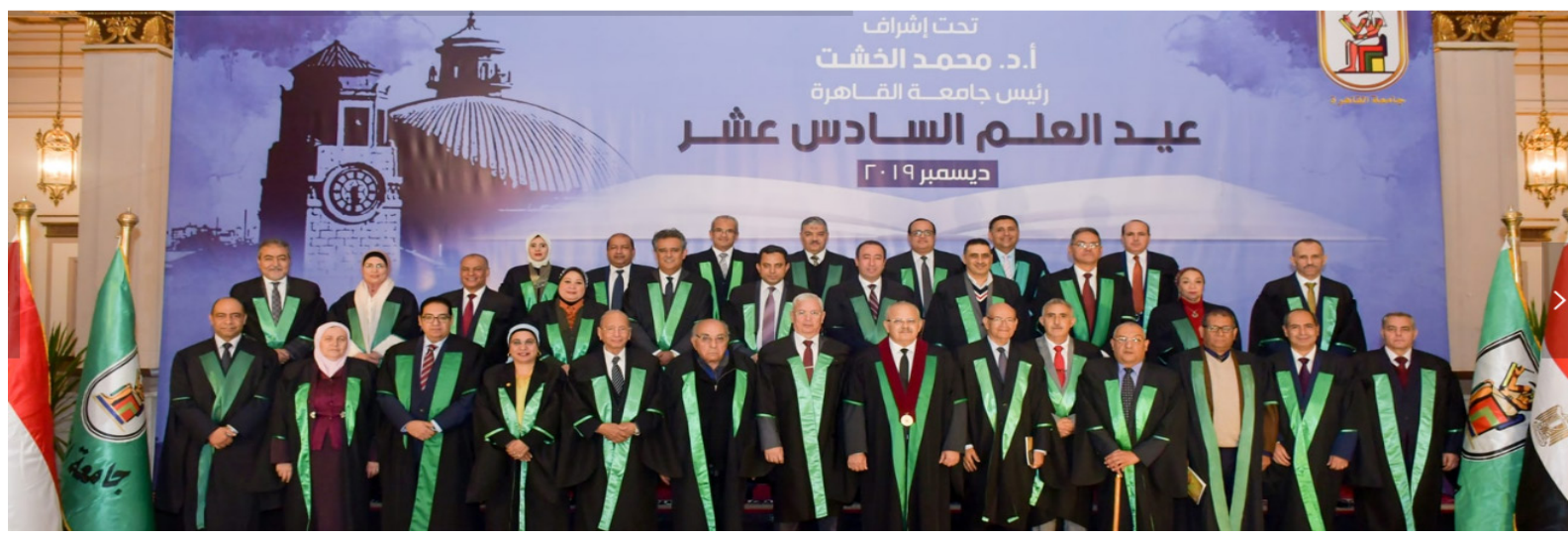

Plate 6. Website for Cairo university
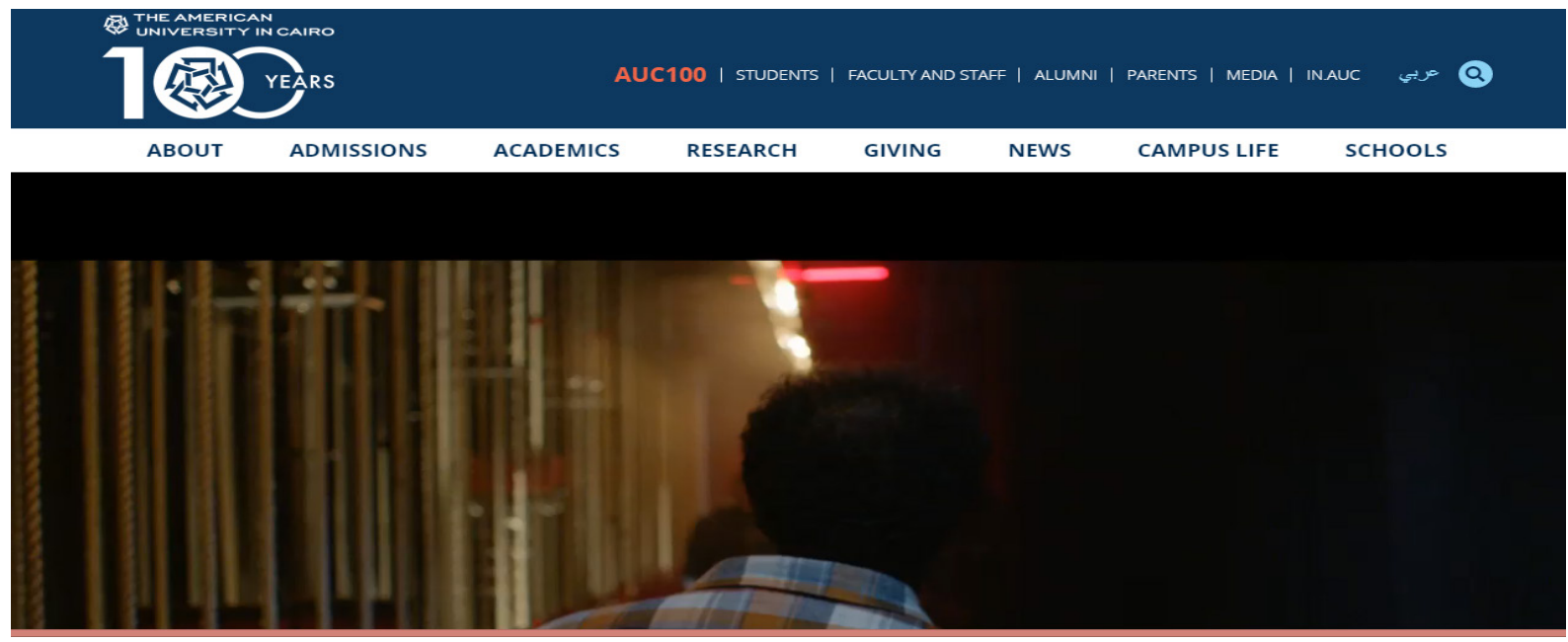

Plate 7. Website for The American University in Cairo 
The University of N'Djamena is the leading institution of higher education in chad, it was established in 1971 as the University of Chad and was renamed to University of N'Djamena in 1994. University of N'Djamena has a website that has little relation with the ideals of the institution. Other social media pages were not active at all and the institution has poor online presence.

University of Dschang is a public University in central Africa, located in the city of Dschang in the west of Cameroon. University of Dschang website has low quality landing page with poor images (https://www.univ-dschang.org/), the site is active with recent contents. The Facebook page (https://web.facebook.com/univdschang?_rdc=1\&_rdr) has a bot that chats you up automatically once you visit the website. 14286 people follow the page. The twitter page (https://twitter.com/univ_dschang) is active with 1682 followers. The tweets are also in French and it has poor engagement. The YouTube page has 137 subsribers with visual contents uploaded in a while.

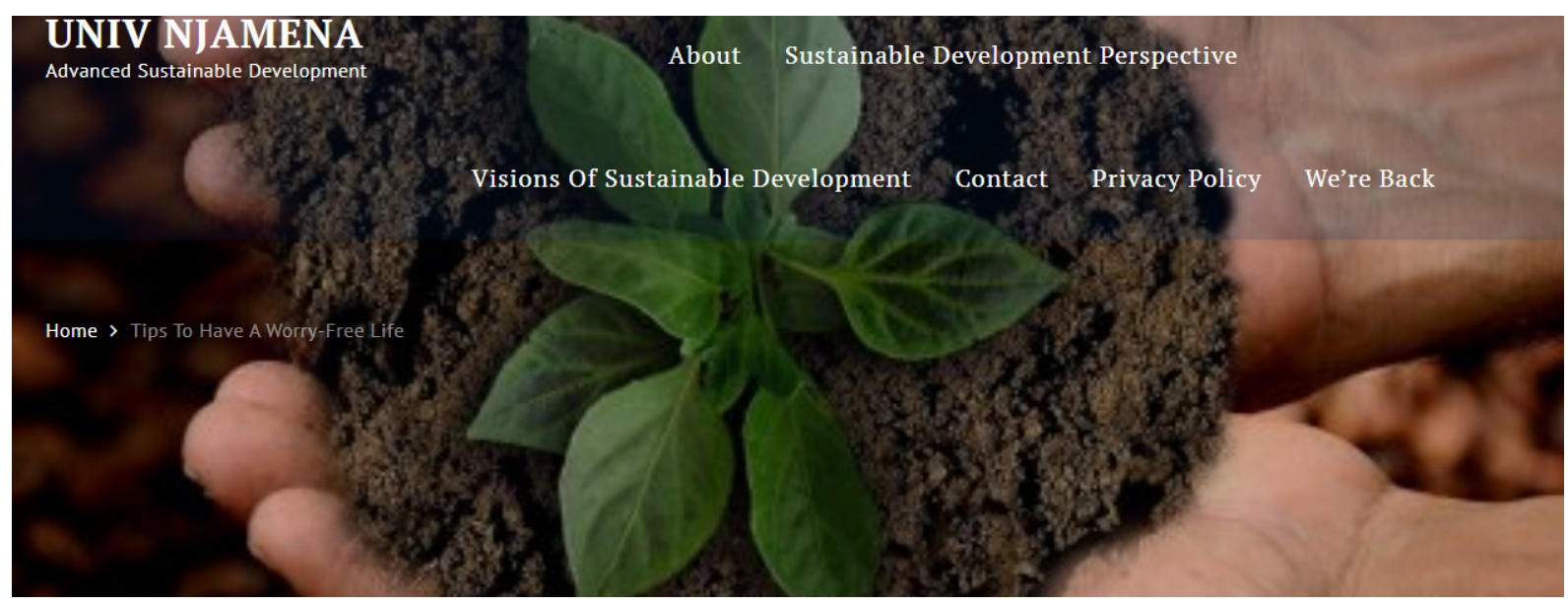

Plate 8. Website for University of N'Djamena

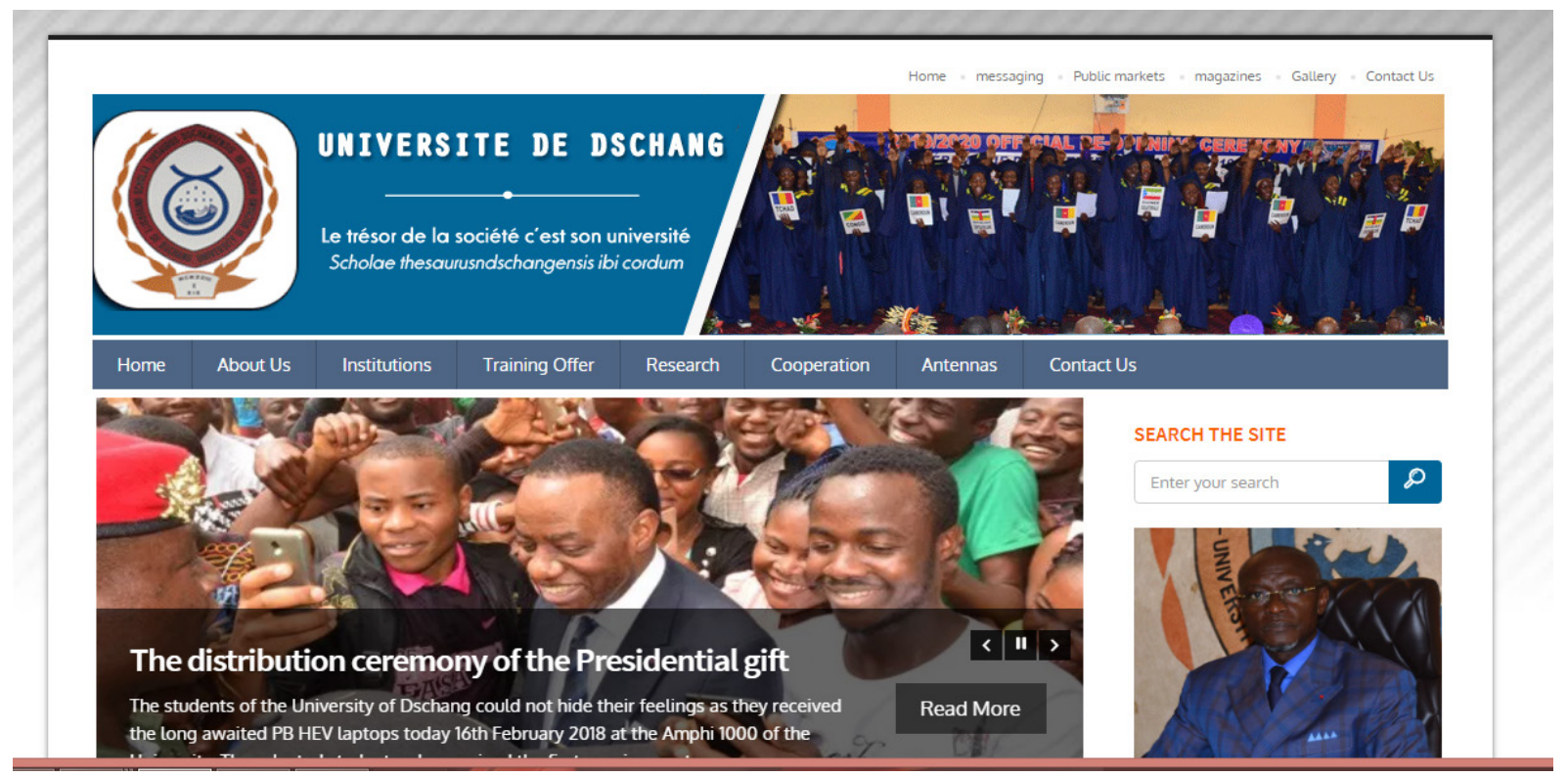

Plate 9. Website for University of Dschang 


\section{Findings and Discussion}

Higher education institutions around Africa are operating in an increasingly competitive environment and this justifies the use of new communication and branding channels including social media. These social media channels are interactive, thereby forcing a dialogue between its users and the institution. Higher education institutions can now take advantage of these channels to discover the needs of their audience, increase the level of engagement, and promote their brands in the process (Mazurek, 2018). Findings from the study reveal that branding and corporate identity are important as core factors in corporate and marketing strategy (Opoku, Abratt\& Pitt, 2006), and higher education institutes are becoming more interested as corporation with brand strategies (Velostsou, Lewis \& Paton, 2004). With various institutions offering service to members of the public, there are various avenues for dishing out information and engaging their prospective clients.

The notable platforms the institutions use include Facebook, twitter, Instagram, LinkedIn and YouTube. Branding has become increasingly important and it has been a major part of corporate and marketing strategy by higher education institutions around the world (Opoku, Abratt\& Pitt, 2006). Findings from the study reveal that few of the universities integrate other platform such as twitter to the website for engagement. It was also found out that there are links to other social media platforms on the website such as LinkedIn, Facebook, twitter, Instagram and YouTube. Zickar, Ron \& Arnold posits that attracting an audience to the brand of these institutions of higher learning using these channels are beneficial. This is because it provides the audience with the appropriate conditions to exchange opinions concerning the institution, leading to a high level of engagement, and creates values within these networks. Branding in the universities considered has leveraged on the power of the social media. The social media has been a veritable tool for branding across these universities. With globalization becoming a major thing in this present clime, it has helped to drive branding strategies of universities. In Africa, there is more access to mobile devices which has helped people to be more connected across various platforms. With a simple click on the mobile devices, information on all aspects of the institution can be accessed via the university website, Facebook page, Instagram account and YouTube page.

This study also finds that as a brand, there is little uniformity on contents posted across all platforms. Some contents on twitter were not posted on Facebook and vice versa. This might be because each social media platform has its peculiarity. Facebook for instance has immense opportunity to share text, video and photos on the timeline, twitter does the same thing but the number of words, videos and photos are limited compared to Facebook. Instagram allows texts, photos and videos but it's still limited compared to Facebook.

\section{Conclusions}

This paper has looked at branding in higher education in Africa using the social media perspective. With the need to massively propagate the institutions across board in Africa, there is the need for branding. This paper examines the various social media platforms used for branding.

The various websites of the institutions considered was the starting point and effort was made to shed light on the website, its architecture and contents posted on it. Various links to other social media pages from the websites were also checked and evaluated to know how universities brand on social media. There were evidences of engagement on Facebook and twitter compared to LinkedIn and YouTube. This might be because Facebook is more prominent and user friendly as a social media platform compared to others. Most institutions considered in this study maintained the same brand identity as they all used the same logo across all platforms. Though, some brand identities were inconspicuous, dull and does not represent the institution well.

\section{Recommendation}

Having looked at some institution in Africa and branding using the social media perspective, this study recommends that the mandate by which each institution was established should be incorporated into their brand identities and propagated via social media. There should be an audit of all social media pages to understand engagement level across all platforms and to proffer other ways of branding to the institution. There is a need to get all social media pages verified to lend credibility and authenticity to each page.

\section{REFERENCES}

[1] Ajayi, J., Lameck, K., Goma, G., \& Johnson, A. (1996). The African Experience with Higher Education, Accra: The Association of African Universities. Athens: Ohio University Press

[2] Altbach, P\& Knight, J, 2007. Internationalization of higher education: Motivations and realities. Journal of Studies in International Education. 11, 290-305

[3] Altbach, P.G, Reisberg, L \&Rumbley, L.E. 2009. Trends in global higher education: Tracking an academic revolution. Report prepared for UNESCO 2009 World Conference on Higher Education. Paris. UNESCO.

[4] Ashby, E. (1961). Patterns of universities in Non-European societies. London. London. University of London school of oriental and African studies. 
[5] Assie-lumuba,N.T (2006). Higher education in Africa. Crisis, reforms and transformation. Dakar: CODESRIA

[6] Assie-Lumumba, N. (2005). Higher Education in Africa: Crises, Reforms and Transformation. Senegal: Council for the Development of Social Science Research in Africa (CODSERIA).

[7] Assie-Lumumba, N. T. (2006). Higher Education in Africa. Crises, Reforms and Transformation. Dakar: Berkeley: University of California Press. http://dx.doi.org/10.1007/BF 00140275

[8] British Council. 2020. The shape of things to come: higher education global trends and emerging opportunities to 2020 . $\mathrm{http}: / /$ britishcouncil.org, higher-education

[9] Building Brands. 2004. Marketing Definitions Brand. (http://www.buildingbrands.com/definitions/02 brand defi nition.shtml)Cambridge: Cambridge University Press.

[10] Castells M. The University system: Engine of development in the new world economy. In: Ransom A, Koo S, Selvaratnam W, editors. Improving higher education in developing countries. Washington DC: The World Bank; 1993. p. 14-40.

[11] Chithra, P. N., \&D'Almeida, S. (2014). Effectiveness of Hand and Foot Massage on Pain among Women who have Undergone Abdominal Hysterectomy in Selected Hospitals at Mangalore. Asian Journal of Nursing Education and Research, 4(3), 337-341.

[12] Cohen, L., Manion, L. and Morrison, K. (2011). Research Methods in Education. New York: Routledge. Clark, B. (1983). The Higher Education System: Academic Organization in a Crossnational Perspective. Berkeley: University of California Press. http://dx.doi.org/10.1007/BF 00140275

[13] Cloete N. The South African higher education system: Performance and policy. Stud High Educ. 2014;39(8):13551368. http://dx.doi.org/10.1080/03075079.2014.949533

[14] Damtew, T. (2003). African Higher Education: An International Reference Handbook. Indiana: IndianaUniver sity Press

[15] Deem,R, Lucas, L, and Mok, K.H. 2008. Transforming higher education in whose image? Exploring the concept of the "world-class" University in Europe and Asia. Higher Education Policy. 21:83-97

[16] Denzin, N. K., \& Lincoln Y. S. (Eds.), (2012). The Landscape of Qualitative Research (4th Ed.). Thousand Oaks, CA: Sage Publications.

[17] Johnson, D. 2005. Trademarks: A history of a billion-dollar business. http://www.shaker.com/in/deb.html

[18] Lulat, Y. G.-M. (2005). A History of African Higher Education from Antiquity to the Present. Westport CT: Praeger Publishers

[19] Makgosa, R \&Molehfi, B.A. (2012). Rebranding an institution of higher education in Botswana. Business and Economic Research. 2(2), 1-13

[20] Mariotti, J. 2000. Smart things to know about Brands \& Branding. United Kingdom: Capstone Publishing Ltd.
[21] Mazurek, G. (2018). E-Marketing. PlanowanieNarzedzia-Praktyka. Warsaw: Poltext.

[22] Mogaji, E. (2018). UK universities corporate visual identities (CVI). Academy of marketing annual conference proceedings. University of Stirling, Stirling, Scotland: Academy of Marketing.

[23] Moore, R. 2004. Brand and Integrated Marketing. (https://www.academicimpressions.com/conferences/0304 brand.htm) Retrieved on 7 January 2005

[24] Opoku, R, Abratt. R \& Pitt, L. (2006). Communicating brand personality: are the websites doing the talking for the top South African Business Schools? Journal of Brand Management. 14(1-2), 20-39

[25] Ridder-Symoens, H. (1992). A History of the University in Europe, Universities in the Middle Ages (Vol. 1).

[26] Roll, M. 2004. Brand Glossary. (http://www.venturerepubli c.com/resources./brand_glossary.asp) Retrieved on 2 March 2005 .

[27] Sevier, R.A. 2004. The Future of Branding in Higher Education. (http://www.stamats.com/applications/stories/futurebrandin g.asp) Retrieved on 11 May 2005

[28] Stewart, P.2004. branding: A way of doing business for everyone. http://allaboutbranding.com $/ \mathrm{html}$

[29] Teferra, D., \&Altbach, P. G. (2004). African Higher Education: Challenges for the 21st Century. Higher Education, 47(1), 21-50. http://dx.doi.org/10.1023/B:HIGH .0000009822 .49980 .30

[30] The Association of African Universities. Athens: Ohio University Press

[31] UNESCO Institute for Statistics. 2020. Higher education. http://uis.unesco.org/en/topic/higher-education University Press

[32] Van den Heever, J. 1993. Brands and branding in South Africa: key success stories. Volume 1. Johannesburg. Affinity advertising and publishing CC Cape Town: National Book Printers

[33] Veloutsou,C, Lewis, J,W \& Paton, R.A (2004). University selection: information requirements and importance. International journal of educational management. 18(3), 160-171

[34] World Bank. (2009). Accelerating Catch-up: Tertiary Education for Growth in Sub-Saharan Africa. Washington,

[35] Baker,S.M, Faircloth,J.B \&Simental, V. 2005. Perceptions of university-corporate partnership influences on a brand. Journal of marketing theory and practice. 13(2), 32-46

[36] Balaji M.S, Roy, S.K \&Sadeque, S. 2016. Antecedents and consequences of university brand identification. Journal of business research. 69(8), 3023-3032

[37] Melewar, T.C \& Nguyen.B. 2014. Five areas to advance branding theory and practice. Journal of brand management. 21(9), 758-769

[38] Chapleo. C and Clark, P. 2016. Branding a tertiary institution by committee: An exploration of internal brand analysis and management processes. Journal of brand 
management, 23(6), 631-647

[39] Belanger,C, Mount J, Wilson, M. 2002. Institutional image and retention. Tertiary education management. 8(3), $217-230$

[40] Helgesen O \&Nesset, E. 2007. Images, satisfaction and antecedents: Driver of student loyalty? A case study of a Norwegian University College. Corporate Reputation Review, 10(1), 39-59

[41] Suomi, K. 2014. Exploring the dimensions of brand reputation in higher education-A case study of a Finnish master's degree programme. Journal of higher education policy and management, 36(6), 646-660

[42] Ressler, J. Abratt, R. 2009. Assessing the impact of university reputation on stakeholder intentions. Journal of General management, 35(1), 35-45

[43] Whisman, R. 2009. Internal branding: A university's most valuable intangible asset. Journal of Product and Brand Management, 18(5), 367-370

[44] Scarborough, E.2007. The branding of higher education: The great awakening in the hallowed halls of academia. Simpson Scarborough. Intelligent marketing for higher education.

[45] Zickar, M., Ron, T., \& Arnold, C. (2018). Using Facebook Pages to Connect with Students, Faculty, Alumni, and Friends: An Empirical Analysis. Teaching of Psychology, 45(4); 358-362. Retrieved from:https://doi.org/10.1177/009 8628318796923 . 